\title{
PENINGKATAN KADAR ALKOHOL, ASAM DAN POLIFENOL LIMBAH CAIRAN $P U L P$ BIJI KAKAO DENGAN PENAMBAHAN SUKROSA DAN RAGI
}

\author{
The Increased Levels of Alcohol, Acid and Polyphenol Waste of Cocoa Bean Pulp \\ Liquid by the Addition of Sucrose and Yeast
}

\author{
St. Sabahannur'), Andi Ralle ${ }^{1)}$ \\ 1)Fakultas Pertanian Universitas Muslim Indonesia \\ JI. Urip Sumoharjo Km 05, Makassar \\ Pos-el: siti_sabahan@yahoo.com
}

\begin{abstract}
The aim of this research is to know the effectivenes of adding yeast and sucrose to increase the level of alcohol, acid and polyphenol liquid of cocoa beans pulp as bioherbisida. The research is arranged in Completely Random Design (RAL) of two factor. The first factor was the addition of yeast with concentration: $0.5 \%$ and $1 \%$, the second factor of sucrose concentration consisted of: $0 \%, 1 \%, 2 \%$, and $3 \%$. The addition of yeast and sucrose is done at the beginning of fermentation by mixing with wet cocoa beans, then seeds in fermentation for 3 days. The pulp liquid dripping out of the fermentation box is accommodated in Waskom. The parameters observed were: alcohol, total acid, acetic acid, citric acid and polyphenol. The results showed that, the addition of yeast and sucrose significantly affected the increase of alcohol content, total acid, acetic acid, citric acid and polyphenol. The addition of $1 \%$ yeast and $2 \%$ sugar produced $0.77 \%$ alcohol content, $65.25 \%$ total acid, citric acid $2740,73 \mathrm{ppm}$, and acetate acid 3915,33ppm, while the highest polyphenol level was 1056,84 ppm in addition of yeast $1 \%$ and $3 \%$ sucrose.
\end{abstract}

Keywords: cocoa pulp, yeast, sucrose, alcohol, polyphenols

Abstrak: Penelitian bertujuan mengetahui efektifitas penambahan ragi dan sukrosa pada peningkatan kadar alkohol, asam dan polifenol cairan pulp biji kakao sebagai bioherbisida Penelitian disusun dalam Rancangan Acak Lengkap (RAL) dua faktor. Faktor pertama penambahan ragitape dengan konsentrasi: $0,5 \%$ dan $1 \%$, faktor kedua konsentrasi sukrosa terdiri atas: $0 \%$, sukrosa $1 \%, 2 \%$, dan $3 \%$. Pemberian ragi dan sukrosa dilakukan pada awal fermentasi dengan cara dicampur dengan biji kakao basah, lalu biji difermentasi selama 3 hari. Cairan pulp yang menetes keluar dari kotak fermentasi ditampung dalam Waskom. Parameter yang diamati terdiri atas: kadar alkohol, total asam, asam asetat, asam sitrat dan polifenol. Hasil penelitian menunjukkan bahwa, penambahan ragi dan sukrosa berpengaruh nyata terhadap peningkatan kadar alkohol, total asam, asam asetat, asam sitrat dan polifenol. Penambahan ragi $1 \%$ dan gula $2 \%$ menghasilkan kadar alkohol 0,77\%, total asam 65,25\%, asam sitrat 2740,73 ppm, dan asam asetat 3915,33 ppm, sedangkan kadar polifenol tertinggi sebesar 1056,84 ppmpada penambahan ragi $1 \%$ dan sukrosa $3 \%$.

Kata kunci: pulp kakao, ragi, sukrosa, alkohol, polifenol

\section{PENDAHULUAN}

Pemanfaatan buah kakao saat ini masih terbatas pada biji dan kulit buah. Buah kakao matang berisi $30-40$ biji yang diselubungi oleh pulp dan plasenta, sebanyak $68,5 \%$ dari berat buah kakao segar terbuang menjadi limbah meliputi: kulit, plasenta, dan pulp (Rohan, 1963; Chahyaditha, 2011). Pulp merupakan jaringan halus yang berlendir yang membungkus biji kakao, zat yang menyusun pulp terdiri atas $80-90 \%$ air, glukosa dan sukrosa antara $12-15 \%$, asam- asam organik dan beberapa asam amino, protein dan lemak, dengan kisaran nilai $\mathrm{pH}$ antara 3-4 (Pettipher, 1986; Effendi, 2002; Opeke, 1984;Bintoro, 1977; Warintek, 2001; Nasution et al., 1985; Wood \& Lass, 1985; Lopez, 1986). Selama fermentasi dapat dihasilkan cairan pulp $15-20 \%$ dari berat biji kakao yang difermentasi (Ganda Putra et al., 2008).Cairan lendir pulp yang dihasilkan dari proses fermentasi satu ton biji kakao dapat mencapai 75-100 liter (Figuera et al., 1993).

Saat ini pemanfaatan pulp kakao belum optimal. Potensi cairan pulp yang 
cukup besar tersebut selama ini hanya dibuang begitu saja disekitar tempat pengolahan, selain akan mengotori juga dapat berdampak buruk atau mencemari lingkungan disekitarnya. Pulp kakao yang selama ini hanya sebagai limbah organik sebenarnya dapat dimanfaatkan sebagai substrat produksi alkohol dan asam asetat. Selain itu limbah pulp juga dapat digunakan sebagai bahan baku pembuatan herbisida alami (Kamaruddin dan Sudirman, 2008), hal ini disebabkan pulp kakao mengandung alkohol, asam malat, asam sitrat, asam asetat dan polifenol yang merupakan beberapa contoh zat kimia yang bersifat allelopat, yaitu dapat menghambat perkecambahan benih.

Untuk meningkatkan kadar alkohol pada cairan pulp, maka penambahan sukrosa merupakan salah satu alternatif. Sukrosa sederhana seperti glukosa dapat langsung difermentasi menjadi alkohol. Bahan yang mengandung senyawa yang lebih kompleks seperti pati atau selulosa harus dihidrolisis menjadi senyawa yang lebih sederhana sebelum difermentasi menjadi alkohol. Hidrolisis dapat dilakukan secara kimiawi atau menggunakan enzim. Medium sukrosa dapat digunakan dengan penambahan enzim invertase sehingga dapat meningkatkan konsentrasi alkohol yang dihasilkan (Purawisastra et al.,1994).

Sukrosa merupakan gula meja yang dikonsumsi sehari-hari. Sukrosa merupakan gula yang ditemukan dalam tebu, komposisinya terdiri dari fruktosa dan glukosa dengan ikatan glukosiklik berupa jembatan oksigen antara C-1 dari glukosa dan C-2 dari fruktosa dimana kedua jenis sukrosa ini selanjutnya disebut dengan sukrosa invert. Sukrosa invert adalah suatu campuran glukosa dan fruktosa yang ekuimolar. Sukrosa dimanfaatkan sebagai salah satu bahan baku dalam hal penyediaan bioenergi, akan tetapi tahapannya tidak bisa langsung menjadi produk akhir tanpa pengubahan menjadi sukrosa sederhana dalam hal ini adalah sukrosa invert. Untuk mempercepat konversinya dibutuhkan sebuah biokatalis atau sering disebut dengan enzim. Enzim memiliki beberapa kelebihan jika dibandingkan dengan katalis biasa. Organisme penghasil enzim ini beragam jenis tetapi yang paling memiliki kandungan baik intraseluler maupun ekstraseluler dan banyak ditemukan adalah jenis khamir Saccaromyces cerevisiae. Khamir ini mempunyai aktivitas invertase yang tinggi sehingga sukrosa dengan cepat diubah menjadi glukosa dan fruktosa untuk keperluan metabolismenya (Ageng dan Surya Rosa Putra, 2009).

Salah satu jenis starter yang mengandung mikroorganisme yang dapat digunakan adalah ragi tape. Ragi tape mengandung Saccharomyces cerevisiae yang mempunyai pertumbuhan sempurna pada suhu sekitar $30^{\circ} \mathrm{C}$ dan $\mathrm{pH} 4,8$. Selain itu pada ragi tape terdapat mikroorganisme yang pada kondisi anaerob akan menghasilkan enzim amilase dan enzim amiloglukosidase, kedua enzim tersebut bertanggungjawab dalam penguraian karbohidrat menjadi glukosa dan maltose. Ragi tape merupakan populasi campuran yang terdiri dari spesiesspesies genus Aspergilius, Saccharomyces, Candida, Hansenulla, dan bakteri Acetobacter (Tarigan, 1988).

Peningkatan proses fermentasi yang terjadi akibat inokulasi mikroorganisme Saccharomyces cerevisiae dan beberapa biakan bakteri lain dapat meningkatkan kinerja fermentasi biji kakao (Schwan, 1998; Widianto et al., 2013). Susijahadi et al. (1998) menjelaskan bahwa konsentrasi awal substrat sukrosa berpengaruh terhadap jumlah alkohol yang dihasilkan, sedangkan Wardani et al. (1991) menyatakan, kadar alkohol maksimum yang dapat diperoleh dari $180 \mathrm{~g} / \mathrm{l}$ sukrosa adalah 12,26\% v/v. Apabila konsentrasi alkohol yang dihasilkan lebih besar dari 12 persen, alkohol dapat menghambat pertumbuhan atau bahkan mematikan mikroorganisme. Pada awal fermentasi, mikroorganisme yang aktif adalah khamir (yeast) yang memecah sukrosa, glukosa dan fruktosa menjadi etanol. Tujuan dari penelitian adalah untuk meningkatkan kadar alkohol, total asam, asam sitrat, asam asetat dan polifenol cairan pulp biji kakao sebagai bahan baku bioherbisida melalui penambahan ragi tape dan sukrosa. 


\section{METODOLOGI}

\section{Bahan dan Alat}

Bahan-bahan yang digunakan dalam penelitian adalah: buah kakao matang, sukrosa,ragi tape, bahan kimia untuk analisa meliputi: $\mathrm{NaOH}$, indikator $\mathrm{pp}$, akuades, kertas lakmus, kertas whatman, dll.

Alat-alat yang digunakan antara lain: Kotak fermentasi, timbangan analitik, thermometer, $\mathrm{pH}$-meter, waskom, alat titrasi, gelas ukur, pipet, ember.

\section{Rancangan Percobaan}

Penelitian disusun berdasarkan Rancangan Acak Lengkap (RAL) pola faktorial dua faktor. Faktor pertama ragi tape $(\mathrm{R})$ terdiri dari dua taraf: $0,5 \%$ dan $1 \%$. Faktor ke dua sukrosa (G) dengan 4 taraf: Tanpa sukrosa (g0), sukrosa $1 \%$ (g1), $2 \%$ (g2), dan 3\% (g3). Jumlah kombinasi perlakuan delapan, masing-masing diulang 2 kali sehingga terdapat 16 unit perlakuan. Data yang diperoleh dianalisis dengan Analysis of Variance (ANOVA), apabila perlakuan berpengaruh nyata dilanjutkan dengan uji BNJ a 0,05 untuk mengetahui perbedaan antar perlakuan.

\section{Metode Penelitian}

Kotak fermentasi yang digunakan dilubangi pada bagian dasarnya, lalu diberi alas daun pisang. Selanjutnya biji kakao basah dimasukkan dalam kotak fermentasi. Biji kakao yang akan difermentasi dicampur sukrosa sesuai perlakuan $(0,1 \%, 2 \%$ dan $3 \%)$, kemudian dicampur lagi dengan ragi tape sesuai dengan perlakuan $(0,5 \%$ dan $1 \%$ ) (ragi terlebih dahulu dihancurkan dengan cara ditumbuk, kemudian diayak dan diaduk hingga homogen). Selanjutnya biji kakao diaduk bersama dengan ragi dan sukrosa agar tercampur rata.
Kotak fermentasi ditempatkan diatas waskom untuk menampung cairan pulp yang menetes keluar selama fermentasi berlangsung. Fermentasi dilakukan selama 3 hari sampai cairan pulp tidak menetes. Cairan pulp disaring dengan menggunakan kertas saring untuk memisahkan kotoran yang tercampur .

\section{Parameter pengamatan}

1. Pengujian kadar alkohol dengan metode piknometer (Putri dan Sukandar, 2008) Kadar alkohol dihitung dengan rumus:

$$
\mathrm{R}=\mathrm{W} 2-\frac{\mathrm{W} 0}{\mathrm{~W} 1}-\mathrm{W} 0
$$

Ket: R: bobot jenis (sampel)

W0: piknometer kosong

W1: piknometer yang berisi air suling

W2: bobot piknometer yang berisi destilasi

2. Total asam Tertitrasi

$\%$ TAT $=m L ~ N a O H \times N ~ N a O H ~(0,1) \times F P \times 100$

Berat sampel $(\mathrm{ml} / \mathrm{g})$

3. Kadar Asam Sitrat

$\%$ TAT $=m L \mathrm{NaOH} \times \mathrm{N} \mathrm{NaOH}(0,1) \times F P \times 100 \times \mathrm{C} 6 \mathrm{H} 07$ Berat sampel $(\mathrm{ml} / \mathrm{g})$

4. Kadar Asam Asetat

$\%$ TAT $=m L ~ N a O H \times N ~ N a O H(0,1) \times F P \times 100 \times \mathrm{CH}_{3} \mathrm{COOH}$ Berat sampel $(\mathrm{ml} / \mathrm{g})$

5. Kadar polifenol dianalisa dengan Metode Kolorimetri Folin-Ciocalteu Fenol (Lee et al., 2003) 


\section{HASIL DAN PEMBAHASAN}

\section{Kadar Alkohol}

Hasil penelitian menunjukkan bahwa penambahan ragi dan sukrosa berpengaruh sangat nyata terhadap kadar alkohol cairan pulp biji kakao. Pengaruh penambahan ragi dan sukrosa terhadap kadar alkohol cairan pulp kakao dapat dilihat pada Tabel 1.

Tabel 1.Presentase alkohol cairan pulp biji kakao

\begin{tabular}{lccc}
\hline \multirow{2}{*}{$\begin{array}{l}\text { Konsentrasi } \\
\text { Sukrosa }\end{array}$} & $\begin{array}{c}\text { Konsentrasi Ragi } \\
(\%)\end{array}$ & \multirow{2}{*}{ BNJ } \\
\cline { 2 - 3 } & 0,5 & 1 & \\
\hline G0 (0\%) & $5,93^{b}{ }_{x}$ & $4,89^{b}{ }_{y}$ & \\
G1 (1\%) & $7,79^{a}{ }_{x}$ & $7,81^{a}{ }_{x}$ & \\
G2 (2\%) & $3,01^{c}{ }_{x}$ & $0,77^{c}{ }_{y}$ & 2,49 \\
G3 (3\%) & $3,28^{c}{ }_{y}$ & $7,19^{a}$ & \\
\hline
\end{tabular}

Keterangan: Angka-angka yang diikuti oleh huruf yang

berbeda pada baris $(a, b, c)$ dan kolom $(x, y)$ yang sama

berarti berbeda nyata pada uji $\mathrm{BNJ}(0,05)$

Berdasarkan uji BNJ 0,05 pada Tabel 1, bahwa penambahan ragi $0,5 \%$ dan $1 \%$ dengan konsentrasi sukrosa $1 \%$ menghasilkan cairan pulp kakao dengan kadar alkohol $7,79 \%$ dan $7,81 \%$ dan berbeda nyata dengan sukrosa $0 \%, 2 \%$ dan $3 \%$ baik pada penambahan ragi $0,5 \%$ maupun $1 \%$. Terjadinya peningkatan kadar alkohol pada konsentrasi ragi $0,5 \%$ dan $1 \%$ yang mencapai puncaknya pada konsentrasi sukrosa $1 \%$ disebabkan karena $S$. Cereviceae mengalami exponensial fase yaitu fase dimana ragi mengalami pertumbuhan yang sangat cepat karena $S$. Cereviceae mampu menggunakan sejumlah sukrosa, glukosa, fruktosa, galaktosa, mannosa, maltosa dan maltotriosa (Lewis dan Young, 1990). Selain itu S.cereviceae merupakan mikrobia yang paling banyak digunakan pada fermentasi alkohol karena dapat berproduksi tinggi, tahan terhadap kadar alkohol yang tinggi, tahan terhadap kadar sukrosa yang tinggi dan tetap aktif melakukan aktivitasnya pada suhu $4-32^{\circ} \mathrm{C}$ (Kartika et al., 1992). Aktivitas ragi banyak dipengaruhi oleh media dan kondisi lingkungan (suhu dan keasaman) dimana panas, konsentrasi ion hidrogen, air dan cahaya mempengaruhi aktivitas pertumbuhan mikroorganisme. Tinggi rendahnya kadar alkohol yang diperoleh sangat dipengaruhi oleh cepat lambatnya sel ragi yang digunakan dalam fermentasi bahan.

Pada tahap awal fermentasi, dengan $\mathrm{pH}$ pulp yang rendah $(3,0-4,0)$ kandungan sukrosa yang tinggi (8-24\%) serta tekanan oksigen yang rendah sangat baik untuk pertumbuhan ragi. Pertumbuhan ragi sangat dominan selama 24-36 jam fermentasi aktivitas ragi sangat kuat dan lebih dari $90 \%$ total mikroorganisme adalah ragi. Ragi memegang peranan pada pemecahan sukrosa menjadi alkohol (Lopez, 1986; Schwan et al., 1998; Leerían and Patterson, 1983).

Ragi tape mengandung Saccharomyces cerevisiae yang mempunyai pertumbuhan sempurna pada suhu sekitar $30^{\circ} \mathrm{C}$ dan $\mathrm{pH} 4,8$. Ragi tape merupakan populasi campuran yang terdiri dari spesies-spesies genus Aspergilius, Saccharomyces, Candida, Hansenulla, dan bakteri Acetobacter (Tarigan, 1988). Menurut Azizah et al. (2012), S.cereviceae dapat mengkonversi sukrosa menjadi alkohol karena adanya enzim invertase dan zymase. Adanya enzim-enzim ini, menyebabkan S. cereviceae memiliki kemampuan untuk mengkonversi baik sukrosa dari kelompok monosakarida maupun dari kelompok disakarida. Jika sukrosa yang tersedia dalam substrat merupakan sukrosa disakarida maka enzim invertase akan bekerja menghidrolisis disakarida menjadi monosakarida. Setelah itu, enzim zymase akan mengubah monosakarida menjadi alkohol dan $\mathrm{CO}_{2}$.

Lama fermentasi yang paling optimal untuk proses pembuatan bioalkohol adalah 3 hari. Jika fermentasi dilakukan lebih dari 3 hari, justru kadar alkoholnya dapat berkurang. Berkurangnya kadar alkohol disebabkan karena alkohol telah dikonversi menjadi senyawa lain. Fermentasi alkohol 
merupakan suatu reaksi pengubahan glukosa menjadi alkohol (etil alkohol) dan karbondioksida fermentasi ini berlangsung dalam keadaan anaerob (Azizah, 2012).

\section{Total Asam}

Berdasarkan hasil penelitian yang diperoleh menunjukkan, bahwa penambahan ragi dan sukrosa berpengaruh sangat nyata terhadap total asam tertitrasi pada cairan pulp biji kakao. Pengaruh penambahan ragi dan sukrosa terhadap total asam cairan pulp biji kakao dapat dilihat pada Tabel 2 .

Tabel 2. Presentase kadar asam cairan pulp biji kakao

\begin{tabular}{|c|c|c|c|}
\hline \multirow{2}{*}{$\begin{array}{l}\text { Konsentrasi } \\
\text { Sukrosa }\end{array}$} & \multicolumn{2}{|c|}{$\begin{array}{l}\text { Konsentrasi Ragi } \\
(\%)\end{array}$} & \multirow{2}{*}{$\begin{array}{l}\text { BNJ } \\
0,05\end{array}$} \\
\hline & $0, x 5$ & $1 \%$ & \\
\hline $\begin{array}{l}\text { G0 }(0 \%) \\
\text { G1 }(1 \%) \\
\text { G2 }(2 \%) \\
\text { G3 }(3 \%)\end{array}$ & $\begin{array}{l}19,78^{a}{ }^{\mathrm{x}} \\
14,47 \mathrm{c}^{\mathrm{x}} \\
21,75^{\mathrm{a}^{\mathrm{y}}} \\
17,34 \mathrm{~b}^{\mathrm{y}}{ }^{\mathrm{x}}\end{array}$ & $\begin{array}{l}16,78{ }^{c}{ }^{y} \\
16,03{ }^{c}{ }^{x} \\
65,25{ }^{a} \\
19,59{ }^{x}{ }_{x}\end{array}$ & 6,48 \\
\hline
\end{tabular}

Keterangan: Angka-angka yang diikuti oleh huruf yang

berbeda pada baris $(a, b, c)$ dan kolom $(x, y)$ yang sama berarti berbeda nyata pada uji BNJ (0.05)

Berdasarkan hasil uji BNJ 0,05pada Tabel 2,bahwa kandungan asam pada cairan pulp kakao terbanyak yaitu $65,25 \%$ pada penambahan ragi $1 \%$ dan sukrosa $2 \%$ dan berbeda nyata dengan perlakuan lainnya, sedangkan kandungan asam terendah ditunjukkan pada penambahan sukrosa $1 \%$ dengan konsentrasi ragi $0,5 \%$ dan $1 \%$. Semakin tinggi konsentrasi ragi yang digunakan maka mikroba yang terdapat pada pulp semakin banyak, sehingga total asam yang dihasilkan juga meningkat. Peningkatan total asam disebabkan terbentuknya asamasam organik sebagai hasil akhir fermentasi yaitu berupa asam asetat dan asam laktat. Asam ini terbentuk dari sukrosa yang ditambahkan dan juga sukrosa, glukosa dan fruktosa yang secara alami terdapat pada pulp biji. Pulp yang tebal berarti mengandung sukrosa yang banyak, selanjutnya sukrosa mengalami fermentasi menjadi alkohol, fermentasi alkohol menghasilkan asam yang banyak pula. Apabila dihubungkan dengan kadar alkohol (Tabel 1), bahwa terjadi penurunan kadar alkohol pada konsentrasi ragi $1 \%$ dan sukrosa $2 \%$, karena sebagian besar alkohol sudah dirombak menjadi asam. Hasil dari penguraian alkohol menghasilkan asam-asam organik seperti asam laktat dan asam asetat. Asam-asam tersebut akan berpengaruh terhadap keasaman $(\mathrm{pH})$ biji setelah fermentasi (Ardhana dan Fleet, 2003; Ramlah \& Daud, 2009; Guehi et al., 2010; Pasau, 2013).

Jenis ragi yang umum terdapat pada tumpukan bijikakao selama fermentasiadalah Saccharomyces cerevisiae, Saccharomyces theobromae, Saccharomyces ellipsoides, Saccharomyces apiculatus dan Saccharomyces apimulus (Nasution et al., 1985). Saccharomyces cerevisiae dan Candida tropicalis merupakan ragi dominan selama fermentasi kakao (Ardhana dan Fleet, 2003). Bakteri asam laktat merupakan bakteri penghasil sejumlah besar asam laktat sebagai hasil akhir dari metabolisme sukrosa. Asam laktat yang dihasilkan dengan cara tersebut akan menurunkan nilai $\mathrm{pH}$ lingkungan pertumbuhannya dan menimbulkan rasa asam (Sulistyowati dan Soenaryo, 1989; Alamsyah, 1991).

Selain itu oksigen yang semula terhalang oleh lapisan pulp dapat masuk kedalam tumpukan biji. Kondisi aerob (kaya oksigen) dimanfaatkan oleh bakteri asetobakteri untuk mengubah alkohol menjadi asam asetat dengan mengeluarkan bau khas yang menyengat. Jenis bakteri asam laktat Lactobacillus cellobiosus dominan sampai 48 jam dan Acetobacter pasteurianus merupakan golongan bakteri asam asetat yang paling lama bertahan hidup dibanding Acetobacter aceti yang aktif pada 24 jam pertama fermentasi.

Walaupun pulp mengandung asamasam organik tetapi bakteri ini tidak beraktifitas pada awal fermentasi karena kondisi ekstrinsik tidak tersedianya oksigen. Laju pertumbuhan bakteri asam asetat akan meningkat setelah tersedianya oksigen dan 
alkohol hasil perombakan bakteri asam laktat dan ragi. Oleh bakteri asam asetat, alkohol dioksidasi menjadi asam asetat dan asam asetat dioksidasi menjadi $\mathrm{CO}_{2}$ dan air (air ini akan keluar dari box fermentasi).

\section{Asam Sitrat}

Hasil penelitian menunjukkan bahwa penambahan ragi dan sukrosa pada fermentasi biji kakao berpengaruh sangat nyata terhadap kandungan asam sitrat cairan pulp kakao. Perbedaan kadar asam sitrat cairan pulp biji kakao pada berbagai konsentrasi ragi dan sukrosa dapat dilihat pada Tabel 3.

Tabel 3. Kadar asam sitrat cairan pulp biji kakao (ppm)

\begin{tabular}{|c|c|c|c|}
\hline \multirow{2}{*}{$\begin{array}{l}\text { Konsentrasi } \\
\text { Sukrosa }\end{array}$} & \multicolumn{2}{|c|}{$\begin{array}{c}\text { Konsentrasi Ragi } \\
(\%)\end{array}$} & \multirow{2}{*}{$\begin{array}{l}\mathrm{BNJ} \\
0,05\end{array}$} \\
\hline & 0,5 & 1 & \\
\hline G0 (0\%) & $830,88^{b}$ & $704,87^{b}$ & \multirow{4}{*}{90,25} \\
\hline G1 $(1 \%)$ & $614,86^{c^{x}}$ & $610,36^{c^{y}}$ & \\
\hline G2 $(2 \%)$ & $929,33^{a^{x}}$ & $2740,73^{x}{ }_{x}$ & \\
\hline G3 (3\%) & $728,50^{c^{y}}$ & $823,01^{b}{ }_{x}^{b}$ & \\
\hline
\end{tabular}

Keterangan: Angka-angka pada kolom yang diikuti oleh huruf yang berbeda (a,b,dan $c)$ dan pada baris yang berbeda $(\mathrm{x}, \mathrm{y})$ berarti berbeda nyata pada uji BNJ (0.05)

Berdasarkan uji BNJ 0,05 pada Tabel 3 menunjukkan, bahwa penambahan ragi $1 \%$ dan sukrosa $2 \%$ memberikan kadar asam sitrat tertinggi $(2740,73 \mathrm{ppm})$ dan berbeda nyata dengan perlakuan lainnya. Fermentasi pada biji kakao terjadi dalam dua tahap yaitu fermentasi anaerob dan fermentasi aerob. Keberadaan asam sitrat membuat lingkungan pulp menjadi asam sehingga akan menginisiasi pertumbuhan ragi dan terjadi fermentasi secara anaerob. Khamir S. Cerevisiae tumbuh dengan baik pada lingkungan dengan keadaan aerobik, namun akan melakukan fermentasi terhadap gula jauh lebih cepat pada keadaan anaerobik. Terurainya pulp selama fermentasi diduga turut menurunkan kadar asam sitrat sehingga menyebabkan peningkatan $\mathrm{pH}$.

\section{Asam Asetat}

Hasil penelitian menunjukkan bahwa penambahan ragi dan sukrosa berpengaruh sangat nyata terhadap kadar asam asetat cairan pulp biji kakao. Perbedaan kadar asam asetat cairan pulp kakao pada berbagai konsentrasi ragi dan sukrosa dapat dilihat pada Tabel 4.

Tabel 4. Rata-rata kadar asam asetat cairan pulp biji kakao (ppm)

\begin{tabular}{lccl}
\hline $\begin{array}{c}\text { Konsentrasi } \\
\text { Sukrosa }\end{array}$ & \multicolumn{2}{c}{ Konsentrasi Ragi (\%) } & BNJ \\
\cline { 2 - 3 } & $\mathbf{0 , 5}$ & $\mathbf{1}$ & $\mathbf{0 , 0 5}$ \\
\hline G0 (0\%) & $1186,98^{b}{ }_{x}$ & $1006,96^{c}{ }_{y}$ & \\
G1 (1\%) & $871,95^{d}{ }^{y}$ & $961,96^{c}{ }_{x}$ & 1388 \\
G2 $(2 \%)$ & $1327,61^{a}$ & $3915,33^{a}{ }_{x}$ & \\
G3 $(3 \%)$ & $1040,711^{{ }^{y}}$ & $1175,73^{b}$ & \\
\hline
\end{tabular}

Keterangan: Angka-angka yang diikuti oleh huruf yang berbeda

pada baris $(a, b, c)$ dan kolom $(x, y)$ yang sama berarti berbeda

nyata pada uji BNJ (0.05)

Berdasarkan uji BNJ 0,05 pada Tabel 4 , bahwa penambahan ragi $1 \%$ dan sukrosa $2 \%$ menunjukkan kandungan asam asetat lebih tinggi yaitu 3915,33 ppm dan berbeda nyata dengan perlakuan lainnya, sedangkan kandungan asam asetat cairan pulp lebih rendah pada penambahan ragi 0,5 dan $1 \%$, dengan sukrosa $1 \%$. Penambahan ragi $1 \%$ dan sukrosa $2 \%$ akan meningkatkan proses fermentasi, di mana sukrosa merupakan substrat yang akan dirombak oleh ragi menjadi etanol. Selanjutnya etanol akan diubah menjadi asam asetat (Chandra et al., 1990). Kandungan gula di dalam pulp dan penambahan sukrosa akan meningkatkan substrat yang dapat dirombak menjadi etanol, sedangkan inokulasi ragi meningkatkan jumlah mikrobia yang bekerja merombak gula menjadi etanol. Fermentasi asam asetat membutuhkan medium yang mengandung etanol $10-13 \%$.

Peningkatan proses fermentasi yang terjadi akibat inokulasi mikroorganisme telah dilaporkan oleh beberapa peneliti. Sebagaimana Schwan (1998) dalam penelitiannya melaporkan bahwa 
penambahan biakan murni Saccharomyces cerevisiae dan beberapa biakan murni bakteri lain dapat meningkatkan kinerja fermentasi biji kakao.

Pada Tabel 4 juga memperlihatkan mulai terjadi penurunan kadar asam asetat 1040,71 ppm apabila konsentrasi sukrosa ditingkatkan menjadi 3\% pada penambahan ragi $0,5 \%$ dan kadar asam asetat 1175,73 ppm pada ragi $1 \%$. Hal ini berkaitan dengan meningkatnya konsentrasi etanol yang dihasilkan. Apabila konsentrasi etanol terlalu tinggi, pembentukan asam asetat akan terganggu, sehingga fermentasi etanol menjadi asam asetat tidak berlangsung dengan sempurna (Darwis dan Sukara, 1989). Damanhuri (2004) menjelaskan fermentasi asam asetat dengan substrat etanol $16,10 \%$ menghasilkan $0,11 \%$ asam asetat dengan lama fermentasi selama 5 minggu. Asam asetat merupakan hasil dua tahap proses fermentasi dimana tahap pertama adalah fermentasi sukrosa menjadi etanol oleh khamir, sedangkan tahap kedua adalah oksidasi etanol menjadi asam asetat oleh bakteri asam asetat (Luwihana, 1998). Substrat dalam fermentasi biji kakao adalah gula dan asam sitrat yang terkandung dalam pulp. Proses fermentasi mikrobia pelaku fermentasi akan merombak pulp menjadi asam-asam organik, selanjutnya Effendi (2002) menyatakan, pada fermentasi etanol hasil fermentasi limbah cair pulp kakao oleh A. Aceti B127 dengan kondisi suhu $30^{\circ} \mathrm{C}$, nilai $\mathrm{pH}$ awal 4 , konsentrasi etanol 5\% (v/v), inokulum 10\% $(\mathrm{v} / \mathrm{v})$, dengan kecepatan pengadukan terbaik $400 \mathrm{rpm}$ menghasilkan asam asetat 4,24\%. Produksi asam sangat bergantung pada tingkat kesuburan pertumbuhan sel bakteri dan tingkat kesuburan tersebut menurun seiring dengan peningkatan kadar etanol substrat (Soedarini et al., 1998).

\section{Polifenol}

Hasil penelitian menunjukkan bahwa penambahan ragi dan sukrosa berpengaruh sangat nyata terhadap kadar polifenol cairan pulp. Untuk mengetahui perbedaan kadar polifenol cairan pulp biji kakao dapat dilihat pada Tabel 5.
Tabel 5. Rata-rata kadar polifenol cairan pulp biji kakao (ppm)

\begin{tabular}{|c|c|c|c|}
\hline \multirow{2}{*}{$\begin{array}{l}\text { Kon- } \\
\text { sentrasi } \\
\text { Sukrosa }\end{array}$} & \multicolumn{2}{|c|}{$\begin{array}{c}\text { Konsentrasi Ragi } \\
(\%)\end{array}$} & \multirow{2}{*}{$\begin{array}{l}\text { BNJ } \\
0,05\end{array}$} \\
\hline & 0,5 & 1 & \\
\hline G0 (0\%) & $1047,36^{a}$ & $804,66^{a}$ & 278,61 \\
\hline G1 (1\%) & $872,06{ }^{a}{ }^{x}$ & $840,36^{a^{x}}$ & \\
\hline G2 (2\%) & $702,23 b_{x}^{b^{x}}$ & $886,76^{a_{x}^{x}}$ & \\
\hline G3 (3\%) & $920,84^{a^{x}}$ & $1056,84^{a}$ & \\
\hline
\end{tabular}

Keterangan:Angka-angka yang diikuti oleh huruf yang berbeda

pada baris $(a, b, c)$ dan kolom $(x, y)$ yang sama berarti berbeda nyata pada uji BNJ (0.05)

Berdasarkan uji BNJ taraf 0,05 pada Tabel 5 menunjukkan, bahwa penambahan ragi $1 \%$ dan sukrosa $3 \%$ menghasilkan polifenol 1056,84 ppm lebih tinggi dibanding perlakuan lainnya, sedangkan ragi $0,5 \%$ dengan sukrosa $2 \%$ menghasilkan polifenol hanya 702,23 ppm. Seperti diketahui bahwa pulp kakao mengandung sejumlah asamasam organik seperti asam malat, asam sitrat dan asam asetat selain itu pulp kakao juga mengandung senyawa polifenol sebanyak $0,17 \%$ yang larut dalam air dan sebanyak $0,15 \%$ yang larut dalam alkohol (Anvoh et al., 2009; Dias et al., 2007). Senyawa asam organik tersebut bersama polifenol merupakan zat kimia yang bersifat allelopati yaitu dapat menghambat perkecambahan biji tanaman (Li et al., 2010; Sing et al., 2001).

Menurut Berri (1985), senyawa fenol berpengaruh terhadap enzim hidrolisis yang berperan dalam memecah cadangan makanan menjadi senyawa-senyawa yang siap dimetabolisme. Kemampuan penghambatan senyawa fenol tergantung konsentrasi (Salisbury dan Ross, 1995), pada konsentrasi tinggi senyawa fenol dapat menaikkan tekanan osmosis, sehingga menghambat difusi air dan oksigen ke dalam biji (Salisbury dan Ross, 1995; Gardner et al., 1991), serta menghambat transport asam amino dan pembentukan protein (Rice, 1984).

Asam fenolat merupakan salah satu dari belasan alelokimia (senyawa penyebab alelopati yang dapat menghambat 
pertumbuhan tanaman lain disekitarnya). Alelokimia dari senyawa fenol menghambat pertumbuhan tanaman melalui beberapa cara, antara lain dengan menghambat pembelahan dan pemanjangan sel, menghambat kerja hormon, mengubah pola kerja enzim, menghambat proses respirasi, menurunkan kemampuan fotosintesis, mengurangi pembukaan stomata, menghambat penyerapan air dan hara serta menurunkan permeabilitas membran (Einhellig, 1995; Devi et al., 1997).

Fenol merupakan senyawa kimia yang banyak dimanfaatkan sebagai insektisida, herbisida dan fungisida. Sebagai herbisida, fenol sangat tinggi toksisitasnya, bersifat non selektif dan bekerja secara efektif merupakan herbisida organik dan sebagian besar bersifat kontak (Oudejans, 1991).

\section{KESIMPULAN}

Berdasarkan hasil penelitian yang diperoleh, maka dapat disimpulkan bahwa penambahan ragi dan sukrosa pada awal fermentasi biji kakao berpengaruh sangat nyata terhadap kadar alkohol, total asam, asam asetat, asam sitrat dan polifenol cairan pulp biji kakao. Penambahan ragi $1 \%$ dan gula $2 \%$ menghasilkan kadar alkohol $0,77 \%$, total asam $65,25 \%$, asam sitrat $2740,73 \mathrm{ppm}$, dan asam asetat 3915,33ppm, sedangkan kadar polifenol terbaik sebesar 1056,84 ppm pada penambahan ragi $1 \%$ dan sukrosa $3 \%$.

\section{UCAPAN TERIMA KASIH}

Ucapan terima kasih disampaikan kepada Kementerian Ristek dan Pendidikan Tinggi atas bantuan dana Penelitian dalam skim Penelitian Terapan, dan Universitas Muslim Indonesia yang telah memberikan izin penelitian, sehingga penelitian dapat dilaksanakan dengan baik.

\section{DAFTAR PUSTAKA}

1. Ageng S., D., Surya Rosa Putra, 2009. Profil Fermentasi Sukrosa Menjadi Etanol Menggunakan Zymomonas Mobilis Yang Dikoamobilkan Dengan Ekstrak Kasar Invertase. Prosiding Tugas Akhir
Semester Genap 2008/2009. Prosiding KIMIA FMIPA - ITS.

2. Alamsyah, T.S. 1991. Peranan fermentasi dalam pengolahan biji kakao kering. Suatu Tinjauan.Berita Perkebunan, 1 (2) : 97-103.

3. Anvoh, K.Y.B., A. Zoro-Bi and D. Gnakri. 2009. Production and characterization of juice from mucilage of cocoa beans and its transformation into marmalade. Pakistan Journal of Nutrition 8(2): 129133.

4. Ardhana, M.M. \& G.H. Fleet, 2003. The microbial ecology of cocoa bean fermentation in Indonesia. International Journal of Food Microbiology 86, 87-99.

5. Azizah N., A. N. Al--Baarri, S. Mulyani, 2012. Pengaruh Lama Fermentasi Terhadap Kadar Alkohol, pH, Dan Produksi Gas Pada Proses Fermentasi Bioetanol Dari Whey Dengan Substitusi Kulit Nanas. Semarang: Fakultas Peternakan dan Pertanian Universitas Diponegoro

6. Bintoro, M.H. 1977. Periode Cukup Panen, Panen dan Periode Setelah PanenCoklat.IPB-Press. Bogor.

7. Chahyaditha E.M. 2011. Pembuatan Pektin dari Kulit Buah Kakao dengan Kapasitas Produksi 20.000 Ton / Tahun. Universitas Sumatra.

8. Darwis A.A, Sukara E. 1989. Penuntun Praktikum Isolasi, Purifikasi, dan Karakterisasi Enzim. Laboratorium Bioindustri, Pusat Antar Universitas Bioteknologi, Institut Pertanian Bogor.

9. Devi, S.R., Pellisier dan Prasad. 1997. Allelochemical. In: M.N.V.Prasad (Eds).1997. Plant Ecophysiology. John Willey and Sons, Inc. Toronto, Canada. 253-303 hlm.

10. Dias, D.R., R.F. Schwan, E.S. Freire and R.D.S. Serodio. 2007. Elaboration of a fruit wine from cocoa (Thebroma cacao L.) pulp. International Journal of Food Science and Technology 42: 319-329

11. Effendi, M.S. 2002. Kinetika fermentasi asam asetat (vinegar) oleh bakteri Acetobacter aceti B127 dari etanol hasil fermentasi limbah cair pulp kakao. J Teknol Ind Pert 13:125-135. 
12. Figueira, A., J. Janick and J.N. BeMiller. 1993. New products from Theobroma cacao: Seed pulp and pod gum. In J. Janick and J.E. Simon (eds.). New Crops. Wiley, New York. p. 475-478.

13. Ganda-Putra, G.P., Harijono, S. Kumalaningsih dan Aulani'am. 2008. Optimasi kondisi depolimerisasi pulp biji kakao oleh enzim polygalaturonase endojinus. Jurnal Teknik Industri 9 (1): 24-34.

14. Guehi, S.T., S. Dabone, L. Ban-Koffi, D.K. Kra, and G.I. Zahouli, 2010. Effect of turning beans and fermentation method on the acidity and physical quality of raw cocoa beans. Advance Journal of Food Science and Technology, 2:163-171.

15. Lehrian, D.W and G.R. Patterson. 1983. Cocoa fermentation, p. 529575. In G.Reed (ed), Biotechnology, comprehensive treatise, vol 5.verlag Chemie, Basel, Switzerland.

16. Li Z.H., Q. Wang, X. Ruan, C.D. Pan. and D.A. Jiang. 2010. Phenolic and plant allelopathy. Molecules 15:8933-8952.

17. Lopez, A.S. 1986. The cocoa pulps soft drink industry in brazil and its effercts on head fermentation. International Cocoa Research Conference.

18. Nasution MZ, Tjiptadi W dan Laksmi BS. 1985. Pengolahan Cokelat. Bogor, Agroindustri Press.

19. Oudejans, JH. 1991. Agro Pesticides: Properties and Function in Integrated Crop Protection. United Nations Bangkok. $329 \mathrm{hlm}$.

20. Opeka LK. 1984. Optimising economic returns(profit) from cocoa cultivation trougheconomic efficient use of cocoa by product. Dalam Sulistyowati, Atmawinata $\mathrm{O}$, Muloto $\mathrm{S}$, Yusianto. 1998. Pemenfaatan limbah bubur pulp kakao untuk pembuatan nata kakao. Pelita Perkebunan 14: 63 - 75.
21. Pasau,C.,2013.Efektivitas penggunaan asam asetat pada pemeraman biji kakao segar sebagai analog fermentasi.E-j. agrotekbis 1 (2) : 113-120.

22. Pettipher, G. L. 1986. Analysis of cocoa pulp and the formulation of a standardised artificial cocoa pulp medium. Journal of the Science and Food Agriculture, 37:297-309.

23. Ramlah, S. \& Daud, D. 2009. Pengaruh Lama Fermentasi Terhadap Warna dan Citarasa Biji Kakao. Jurnal Industri Hasil Perkebunan, 4: 24-30.

24. Rohan,T.A. 1963. Proccesing of Raw Cocoa for The Market. Food and Agricultural Organization of The United National, Rome

25. Salisbury, F.B. dan C.W. Ross. 1995. Fisiologi Tumbuhan. Terjemahan Lukman dan Sunaryono. ITB, Bandung. $338 p$

26. Schwan, R.F. 1998. Cocoa fermentations conducted with a defined microbial cocktail inoculum. Appl. Environ Microbiol., 64 (4) : 1477-1483.

27. Sulistyowati dan Soenaryo. 1989. Optimasi Lama Fermentasi dan Perendaman Biji Kakao Mulia.Pelita Pekebunan. Vol. 5 (1): 37-45.

28. Sing, H.P., R.K. Kohli. and D.R. Batish. 2001. Allelopathy in agroeco systems: An overview. Journal of Crop Production 4: $1-41$. 